Transl Res. 2017 June ; 184: 68-76. doi:10.1016/j.trs1.2017.03.003.

\title{
Skin microbiome and mast cells
}

\author{
Satomi Igawa ${ }^{1,2}$ and Anna Di Nardo ${ }^{2, *}$ \\ ${ }^{1}$ Department of Dermatology, Asahikawa Medical University, Asahikawa, Japan \\ ${ }^{2}$ Department of Dermatology, University of California, San Diego, USA
}

\section{INTRODUCTION}

Mast cells (MCs) are particularly frequent in the skin, airway and gut mucosa, where they are strategically located for optimal interaction with the environment and for their putative functions in host defense [1] and wound healing. They are regarded as major effector cells of immunoglobulin E (IgE)-mediated allergic inflammation. However, it has become clear that they also play important roles in both innate and adaptive immune responses. MCs possess a variety of surface receptors, including Toll-like and other microbe-associated pattern recognition receptors, and are activated by inflammatory mediators, $\operatorname{IgE}, \operatorname{IgG}$, light chains, complement fragments, proteases, hormones, neuropeptides, and microbial products [2, 3]. Following activation, they produce a plethora of pro-inflammatory mediators and participate in inflammatory reactions in many organs [2].

MCs have a hematopoietic origin and migrate as immature progenitor cells through the blood stream to peripheral tissues where they complete their maturation [4]. Stem cell factor (SCF) is essential for MC survival and development in vitro [5]. Other growth factors and cytokines can also influence maturation of MCs and contribute to determine the mature MC phenotype. Depending on the microenvironment they encounter, different subsets of mature MCs have been described [6-9].

An increased understanding of the importance of the microbiome to the normal physiology of mammals has led to a paradigm shift in immunology. The idea that the relationship between immunity and microbes is purely adversarial has been supplanted by an appreciation that the immune system has not only evolved to protect against pathogens, but also promotes and encourages a healthy microbiota. Under this paradigm, the role of MCs on the frontline of defense against pathogens suggests that they may also play an important role in fostering the host-microbiome relationship [3].

Although roles of MCs in the host-microbiome relationship have been well described, mainly in gut microbiomes [10-13], in this review we focus on the role of MCs in the skin

\footnotetext{
*Corresponding author: Anna Di Nardo, Department of Dermatology, University of California, San Diego, 9500 Gilman Dr. \#0869 La Jolla, CA 92093-0869, Tel.: 858822 6712, adinardo@ucsd.edu.

Publisher's Disclaimer: This is a PDF file of an unedited manuscript that has been accepted for publication. As a service to our customers we are providing this early version of the manuscript. The manuscript will undergo copyediting, typesetting, and review of the resulting proof before it is published in its final citable form. Please note that during the production process errors may be discovered which could affect the content, and all legal disclaimers that apply to the journal pertain.
} 
and microbiomes of the skin, which have unique and different characteristics and functions from gut microbiomes $[14,15]$.

\section{MAST CELL HETEROGENEITY}

MC phenotypes are different, not only in different species, but also in different organs or tissues within the same species. In humans, the density of MCs has been described to be up to 500 to 4,000 cells $/ \mathrm{mm}^{3}$ in the lungs, 7,000 to 12,000 cells $/ \mathrm{mm}^{3}$ in the skin and 20,000 cells $/ \mathrm{mm}^{3}$ in the gut [16]. The distribution of MCs in each organ is also strategic [17, 18]. For instance, in human skin, the densities of MCs tend to be higher in the forearms and lower legs, suggesting that regions that experience continual environmental exposure respond by either inducing more MC recruitment or proliferation in the local area [18].

A distinction of MCs established in mice is that connective tissue MCs (CTMCs) are constitutive and T cell-independent, while mucosal MCs (MMCs) are transient, induced in pathological settings, and T cell-dependent $[4,19]$. CTMCs are detected mainly in the skin, peritoneal cavity, submucosal layer of the gut, and lung interstitium. Their granules contain heparin, as well as large amounts of histamine, and carboxypeptidase A3 (CPA3), and they can respond to cationic compounds (such as compound 48/80) by degranulating In contrast, MMCs are usually found in the mucosal epithelium of the gut or lung. Their granules contain chondroitin, relatively lower amounts of histamine and CPA3, and show little or no response to cationic compounds [4, 19-21]. Although both MMCs and CTMCs express many kinds of serine proteases, including mouse MC proteases (mMCPs), their protease phenotypes are different depending on the location of the MCs [4, 22-25]. CTMCs in the skin and small intestine exhibit constantly stable expression of mMCP-4, 5, 6, 7, and CPA3, whereas in the small intestine, helminth-induced MMCs express only mMCP-1 [22, 25]. After seven daily challenges with aerosolized antigen to OVA-albumin sensitize BALB/c mice, both MMCs and CTMCs express mMCP-1, 2, 4, 5, 6, 7, and CPA3 in the trachea. In the large airway of the lung, CTMCs show the same expression pattern as in the trachea, but MMCs express only mMCP-1, 2, 6, and 7 [22] (Table 1).

In humans, $\mathrm{MC}$ subsets are usually classified into two types according to their protease content [21]. One subset of MCs contain only tryptase (MCT) and are mainly found in mucosal surfaces such as lung or gut epithelium (these are thought to resemble MMCs in rodents). The other subset of MCs contain tryptase, chymase, cathepsin G, and CPA (MCTC), and tend to reside for a long time within connective tissues (such as skin), submucosal tissues of the gut, and pulmonary perivascular tissues [17, 26] (these are thought to resemble CTMCs in rodents). The MCT/MCTC ratio is different in each tissue, but MCs that reside in skin are almost always MCTCs [17, 26] (Table 2).

While the classification of human MCs based on protease content is convenient, some studies have challenged these designations [29, 30]. For example, MCs containing chymase and $\mathrm{CPA}$, but no tryptase $\left(\mathrm{MC}_{\mathrm{C}}\right)$, exist $[27,28]$, but their location and function have yet to be elucidated. Furthermore, MCs infiltrating the airway epithelium in asthma express both tryptase and CPA, but not chymase [29], and MCs derived from adult peripheral blood progenitors express the full repertoire of MC proteases [30]. These data suggest that all MCs 
arise from a common progenitor and that the local cytokine environment and cell-cell as well as cell-matrix interactions determine the levels of protease expression in MCs in each tissue type.

\section{MAST CELL ACTIVATION}

The skin has an important barrier function for exogenous hazards such as microbes, antigens, toxins, and physical stimuli. MCs support this barrier function and can act as sentinels in the skin. In MC activation, the most studied method is the allergic reaction, an adaptive immune response mediated by the high-affinity IgE receptor on the surface of MCs [31]. The role of MCs in innate immune regulation has also become important. MCs can recognize pathogens through different mechanisms including direct binding of pathogens or their components to pathogen-associated molecular pattern (PAMP) receptors on their cell surface [32]. Toll-like receptors (TLRs), Nod-like receptors (NLRs), retinoic acid-inducible gene 1 (RIG-I)-like receptors (RLRs), and receptors for complement cause most innate immune responses in MCs [33-36]. Once pathogens activate these receptors, inflammatory mediators are released. These mediators contribute to containing and clearing the infection and support adaptive immune responses, if necessary.

The expression patterns of PAMPs are different among MC subtypes in tissues. As summarized in Table 2, Kulka and Metcalfe showed some differences in TLR expression between ex vivo skin and lung MCs [37]. Motakis et al. also showed TLR expression in ex vivo skin and primary cultured skin MCs, but the expression patterns they observed were slightly different from those shown by Kulka and Metcalfe [37, 38]. Moreover, they showed that the expression levels of skin MC TLRs were much lower than those observed in other immune cells under stable conditions and that skin MCs can change their TLR expression levels when kept in culture [38]. McCurdy et al. also showed different expression patterns of TLRs in cord blood-derived mast cells (CBMCs) [39].

Recently, it has been proven that activation of TLR2, $-3,-4,-6,-7$, and -9 can induce degranulation and release of various cytokines by skin MCs [1, 34, 40, 41]. TLR2 recognizes peptidoglycans from gram-positive bacteria and mycobacteria. Supajatura et al. has also shown that Staphylococcus aureus-derived peptidoglycans can induce TLR2 during MC-dependent skin vasodilation and inflammation using the MC knock-in model [1]. TLR3 on the MC surface is the sensor for double-stranded RNA (dsRNA) and induces the production of antiviral cytokines, such as TNF- $\alpha$ and IFN- $\beta$, without MC degranulation [42]. Single-stranded viral RNA is sensed by TLR7 and TLR8, whereas viral DNA is detected by TLR9 [43]. MCs also express RIG-I protein kinase RNA-activated (PKR), and melanoma differentiation-associated gene 5 (MDA5), which recognize viral and synthetic dsRNA and induce MC activation and antiviral cytokine and chemokine production without degranulation $[35,36]$. Human $\beta$-defensin- 3 and 4 can also contribute to MC degranulation, prostaglandin $\mathrm{D}_{2}$ generation, and chemotaxis [44]. 


\section{BACTERIAL INFECTION}

During bacterial infection, MCs facilitate bacterial clearance with their pathogen recognition ability and their release of mediators that induce increased vascular permeability and attract other immune cells [9]. MCs can also produce antimicrobial peptides (AMPs), such as cathelicidins, and have direct bactericidal activity [45, 46]. Cathelicidins in MCs are activated by TLR 2 and TLR4 ligands [45, 47]. Moreover, the importance of cathelicidin activity for MC function has been demonstrated during group A Streptococcus skin infection; thus, not only cathelicidin derived from MCs kill bacteria directly, but also the presence of cathelicidin in MCs may act to facilitate recruitment of neutrophils [48] (Figure 1). It has also been demonstrated that MCs represent sentinel cells in the upper dermis, as their presence not only fights infection locally, but also prevents bacterial spread into the bloodstream [48]. On the other hand, when MCs are exposed to a very large number of bacteria, the dying MCs exert their extracellular antimicrobial activity against Streptococcus pyogenes through the production of extracellular structures called MC extracellular traps (MCETs), which are composed of DNA, histones, and granule proteins such as tryptase and cathelicidin LL-37 [49] (Figure 1).

\section{VIRAL INFECTION}

In viral infections, MCs are involved in the initiation of a chemokine-dependent host response [50-55] and release histamine in response to viral contact [50, 56, 57]. Aoki et al. showed the importance of MCs in host defense at herpes simplex virus (HSV)-2-infected sites through TNF- $a$ and interleukin 6 (IL-6) production induced by keratinocyte-derived IL-33 [58]. In addition, Kurt-Jones et al. reported that TLR2 is a target for HSV-1 and that the TLR2-mediated cytokine response to HSV-1 is detrimental to the host [59]. Furthermore, Zhu et al. reported that innate immune recognition of vaccinia virus (VV) is mediated by TLR2; thus, TIr $2^{-/-}$mice fail to produce proinflammatory cytokines after challenge with VV [60]. We have demonstrated that MCs degranulate upon VV fusion via interaction with the viral lipid envelope and that the response to VV in skin is substantially mediated by degranulation and cathelicidin expression in MCs [43]. This cathelicidin induction is caused by lipoteichoic acid (LTA), which is a TLR2 ligand [61] (Figure 2). Moreover, LTApreconditioned wild-type MCs show increased AMP expression and greater antiviral response compared to pretreated Tlr $2^{-/-}$MCs. Blocking the release of granules with cromolyn abolished this response, confirming that LTA-induced AMP release is important. Furthermore, cathelicidin-deficient MCs could not improve their VV killing capacity after stimulation with LTA. These data also confirmed that LTA improved MC VV killing capacity through cathelicidin AMP [61]. This study revealed that LTA, released by bacteria at the skin surface, has the potential to be a potent mechanism to keep MCs vigilant at the port of entry of infections and to increase their capacity to fight viruses that use skin as an entry point.

\section{SKIN INFLAMMATORY DISEASES}

The skin of patients with atopic dermatitis (AD) shows greatly reduced microbial diversity relative to the same skin area of healthy controls. Staphylococcus aureus is found on the skin 
in more than $90 \%$ of those affected with $\mathrm{AD}$, though it is rarely present on healthy skin. Fortunately, there are some treatments to reduce Staphylococcus aureus colonization to decrease disease severity [62]. Moreover, it has been shown that the microbiome composition of lesional skin in children with moderate-to-severe cases of AD shifted temporally in association with disease flares and treatment [63]. Specifically, the relative abundance of Staphylococcus aureus and the skin commensal Staphylococcus epidermidis was increased with disease severity, while Streptococcus, Propionibacterium, and Corynebacterium genera were increased with treatment [63]. Peptidoglycans from Staphylococcus aureus have the ability to recruit MCs to the dermis through TGF- $\beta$ produced by epidermal keratinocytes; thus, colonized Staphylococcus aureus in the AD skin surface might affect skin inflammation [64]. Nakamura et al. identified that $\delta$-toxin, produced by Staphylococcus aureus, induces MC degranulation and that Staphylococcus aureus isolates recovered from patients with AD produce large amounts of $\delta$-toxin. Furthermore, $\delta$-toxin-induced MC degranulation was enhanced by IgE in the absence of antigen. In addition, skin colonization with Staphylococcus aureus, but not a mutant deficient in $\delta$-toxin, increased IgE and IL-4 production and promoted inflammatory skin disease. Crucially, the enhancement of IgE production and dermatitis by $\delta$-toxin was abrogated in MC-deficient $\mathrm{Kit}^{\mathrm{W}-\mathrm{sh} / \mathrm{W}-\mathrm{sh}}$ mice and restored by MC reconstitution [65]. This study identified that $\delta$-toxin is a potent inducer of MC degranulation and suggested a mechanistic link between Staphylococcus aureus colonization and allergic skin disease.

$\mathrm{P} 2$ purinoceptors, $\mathrm{P} 2 \mathrm{X} 1$ to $\mathrm{P} 2 \mathrm{X} 7$, act as extracellular-ATP receptors [66]. Extracellular ATP stimulates MCs to release inflammatory cytokines, chemokines, and lipid mediators in a P2X7-dependent manner [67, 68]. Cathelicidin-derived peptide LL-37 can also directly stimulate P2X7 [69]. P2X7 is highly expressed on colonic MCs and P2X7-expressing MCs accumulate at lesional sites of Crohn's disease [67]. Conversely, skin MCs show low expression of $\mathrm{P} 2 \mathrm{X} 7$ [67]. To maintain low expression of $\mathrm{P} 2 \mathrm{X} 7$, skin fibroblasts produce the retinoic acid (RA)-degrading enzyme CYP26B1. Increased ATP production in RA-treated skin causes P2X7- and MC-dependent skin inflammation, known as retinoid dermatitis. Kurashima et al. reported that the skin inflammation induced by RA treatment was reduced in $\mathrm{Tlr}^{\mathrm{-}^{--}}, \mathrm{MyD} 88^{-/-}$, and germ-free (GF) mice, and that cathelicidin expression was low in RA-induced skin inflammation lesions in GF mice. These data suggest that the skin microbiota induces TLR2-dependent production of P2X7 ligands, such as ATP and LL-37, from inflammatory monocytes and that such ligands activate MCs via P2X7. This pathway is critical for the development of retinoid dermatitis [70].

Rosacea is a chronic inflammatory skin disease. Frequent flares occurring without specific triggers harm many patients and, when left untreated, can take weeks to subside [71]. The formation of an aberrant AMP, cathelicidin LL-37, on the skin surface has been previously implicated as a key initiator of rosacea [72] and accompanies TLR2 overexpression on epidermal keratinocytes [73]. Demodex mites are present at a higher density in rosaceaaffected skin [74], suggesting pathogenic association. We have demonstrated that cathelicidin LL-37, which is released from the epidermis in rosacea skin, activates skin MCs to release proteases such as matrix metalloproteinase (MMP) 9 and IL-6 [75]. These data were underscored by recent work showing that doxycycline, which is an effective therapeutic for improving rosacea symptoms, inhibits MMPs directly [76]. 


\section{AUTOINFLAMMATORY DISEASES}

Cryopyrin-associated periodic syndrome (CAPS) is a group of autoinflammatory syndromes caused by autosomal dominant mutations in the cryopyrin-coding gene NLRP3 (Nod-like receptor, containing pyrin domain 3), also known as CIAS1, PYPAF1 or NALP3 [77]. Clinical manifestations, such as periodic fever and "urticaria-like rash", that develop in the neonatal or early infant period are hallmarks of CAPS [78]. In addition, microbial components, such as lipopolysaccharide (LPS), peptidoglycan, and bacterial CpG DNA, are potent stimuli for initiating NLRP3 inflammasome activation [79]. All of these observations suggest that some environmental factors, even non-pathological bacterial colonization of the skin, may play a role in developing cutaneous manifestations. Indeed, Nakamura et al. revealed that the microbiome in the skin induces local production of TNF- $a$ from MCs, which primes MCs themselves to elicit dysregulated production of IL-1 $\beta$, causing skin and systemic disease in neonatal mice with the CAPS-associated NIrp3 mutation [80].

\section{THE MICROBIOME INFLUENCE}

Changes in the microbiome have been connected with different skin diseases such as AD, acne, and psoriasis [81]. Specific commensal bacteria, such as Staphylococcus epidermidis, have been implicated in the modulation of skin responses to diseases [82] and recent studies suggest that the skin microbiota may play a functional role in immune cell modulation and differentiation [81]. However, little is known about whether or how the skin microbiome modulates the differentiation, survival, and function of MCs. Our group has recently published that the skin microbiome influences MC maturation in the dermis and that a normal microbiome is necessary for correct function and maturation of MCs [83]. In fact, in GF mice, MCs present lower expressions of the c-Kit and IgE receptors (Figure 3). Moreover, upon co-housing GF mice with specific pathogen-free (SPF) mice, GF mice regained their microbiome and converted back to a normal MC phenotype. Furthermore, when GF mice were stimulated in vivo with compound 48/80 injections in the skin, the resulting inflammation was much lower than in the SPF mice, suggesting altered MC function [83]. This discovery is of fundamental importance for a better understanding of the genesis of skin diseases like $\mathrm{AD}$ in which changes in the skin microbiome have been considered to be responsible for eczema flares.

\section{CONCLUSION}

Given the role of MCs as immune sentinels in the skin and mucosal surfaces, it is not surprising that these cells are involved in both defense against pathogens and in maintaining the beneficial relationship between the host and their microbiomes. In this review, we focused on the roles of the skin microbiome and MCs. The relationships between the two are wide-ranging, not only in preventing pathogens from invading through the skin, but also in modifying inflammation and associated disease pathogenesis. Improving our understanding of this relationship has the potential to create new strategies for treatment such as topical cromolyn for the lesions of rosacea [75]. 


\section{Abbreviations}

AD atopic dermatitis

AMP antimicrobial peptide

CAPS cryopyrin-associated periodic syndrome

CPA carboxypeptidase A

CTMC connective tissue mast cell

dsRNA double-stranded RNA

GF germ-free

HSV herpes simplex virus

Ig immunoglobulin

IL interleukin

LPS lipopolysaccharide

LTA lipoteichoic acid

MC mast cell

MDA5 melanoma differentiation-associated gene 5

MMC mucosal mast cell

mMCP mouse mast cell protease

MMP matrix metalloproteinase

NLR nod-like receptor

NLRP3 nod-like receptor, containing pyrin domain 3

PAMP pathogen-associated molecular pattern

PKR protein kinase RNA-activated

RA retinoic acid

RIG-I retinoic acid-inducible gene 1

RLR retinoic acid-inducible gene 1-like receptor

SCF stem cell factor

TLR Toll-like receptor

VV vaccinia virus 


\section{References}

1. Supajatura V, Ushio H, Nakao A, Akira S, Okumura K, Ra C, et al. Differential responses of mast cell Toll-like receptors 2 and 4 in allergy and innate immunity. J Clin Invest. 2002; 109:1351-9. [PubMed: 12021251]

2. Vliagoftis H, Befus AD. Rapidly changing perspectives about mast cells at mucosal surfaces. Immunol Rev. 2005; 206:190-203. [PubMed: 16048550]

3. Forsythe P. Microbes taming mast cells: Implications for allergic inflammation and beyond. Eur J Pharmacol. 2016; 778:169-75. [PubMed: 26130124]

4. Gurish MF, Austen KF. Developmental origin and functional specialization of mast cell subsets. Immunity. 2012; 37:25-33. [PubMed: 22840841]

5. Gurish MF, Ghildyal N, McNeil HP, Austen KF, Gillis S, Stevens RL. Differential expression of secretory granule proteases in mouse mast cells exposed to interleukin 3 and c-kit ligand. J Exp Med. 1992; 175:1003-12. [PubMed: 1372640]

6. Enerback L. Mast cells in rat gastrointestinal mucosa. I. Effects of fixation. Acta Pathol Microbiol Scand. 1966; 66:289-302. [PubMed: 4162017]

7. Enerback L. Mast cells in rat gastrointestinal mucosa. 2. Dye-binding and metachromatic properties. Acta Pathol Microbiol Scand. 1966; 66:303-12. [PubMed: 4162018]

8. Pejler G, Ronnberg E, Waern I, Wernersson S. Mast cell proteases: multifaceted regulators of inflammatory disease. Blood. 2010; 115:4981-90. [PubMed: 20233968]

9. Feger F, Varadaradjalou S, Gao Z, Abraham SN, Arock M. The role of mast cells in host defense and their subversion by bacterial pathogens. Trends Immunol. 2002; 23:151-8. [PubMed: 11864844]

10. Forsythe P, Wang B, Khambati I, Kunze WA. Systemic effects of ingested Lactobacillus rhamnosus: inhibition of mast cell membrane potassium (IKCa) current and degranulation. PLoS One. 2012; 7:e41234. [PubMed: 22815978]

11. Gueniche A, Benyacoub J, Philippe D, Bastien P, Kusy N, Breton L, et al. Lactobacillus paracasei CNCM I-2116 (ST11) inhibits substance P-induced skin inflammation and accelerates skin barrier function recovery in vitro. Eur J Dermatol. 2010; 20:731-7. [PubMed: 20965806]

12. Kasakura K, Takahashi K, Itoh T, Hosono A, Momose Y, Itoh K, et al. Commensal bacteria directly suppress in vitro degranulation of mast cells in a MyD88-independent manner. Biosci Biotechnol Biochem. 2014; 78:1669-76. [PubMed: 25273132]

13. Afrin LB, Khoruts A. Mast Cell Activation Disease and Microbiotic Interactions. Clin Ther. 2015; 37:941-53. [PubMed: 25773459]

14. Kong HH, Segre JA. Skin microbiome: looking back to move forward. J Invest Dermatol. 2012; 132:933-9. [PubMed: 22189793]

15. Grice EA, Kong HH, Renaud G, Young AC, Program NCS, Bouffard GG, et al. A diversity profile of the human skin microbiota. Genome Res. 2008; 18:1043-50. [PubMed: 18502944]

16. Wasserman SI. Mast cell-mediated inflammation in asthma. Ann Allergy. 1989; 63:546-50. [PubMed: 2688493]

17. Andersson CK, Mori M, Bjermer L, Lofdahl CG, Erjefalt JS. Novel site-specific mast cell subpopulations in the human lung. Thorax. 2009; 64:297-305. [PubMed: 19131451]

18. Janssens AS, Heide R, den Hollander JC, Mulder PG, Tank B, Oranje AP. Mast cell distribution in normal adult skin. J Clin Pathol. 2005; 58:285-9. [PubMed: 15735162]

19. Metcalfe DD, Baram D, Mekori YA. Mast cells. Physiol Rev. 1997; 77:1033-79. [PubMed: 9354811]

20. Reber LL, Sibilano R, Mukai K, Galli SJ. Potential effector and immunoregulatory functions of mast cells in mucosal immunity. Mucosal Immunol. 2015; 8:444-63. [PubMed: 25669149]

21. Bradding P, Arthur G. Mast cells in asthma-state of the art. Clin Exp Allergy. 2016; 46:194-263. [PubMed: 26567481]

22. Xing W, Austen KF, Gurish MF, Jones TG. Protease phenotype of constitutive connective tissue and of induced mucosal mast cells in mice is regulated by the tissue. Proc Natl Acad Sci U S A. 2011; 108:14210-5. [PubMed: 21825171] 
23. Friend DS, Ghildyal N, Austen KF, Gurish MF, Matsumoto R, Stevens RL. Mast cells that reside at different locations in the jejunum of mice infected with Trichinella spiralis exhibit sequential changes in their granule ultrastructure and chymase phenotype. J Cell Biol. 1996; 135:279-90. [PubMed: 8858180]

24. Friend DS, Ghildyal N, Gurish MF, Hunt J, Hu X, Austen KF, et al. Reversible expression of tryptases and chymases in the jejunal mast cells of mice infected with Trichinella spiralis. $\mathrm{J}$ Immunol. 1998; 160:5537-45. [PubMed: 9605158]

25. Stevens RL, Friend DS, McNeil HP, Schiller V, Ghildyal N, Austen KF. Strain-specific and tissuespecific expression of mouse mast cell secretory granule proteases. Proc Natl Acad Sci U S A. 1994; 91:128-32. [PubMed: 8278352]

26. Irani AA, Schechter NM, Craig SS, DeBlois G, Schwartz LB. Two types of human mast cells that have distinct neutral protease compositions. Proc Natl Acad Sci U S A. 1986; 83:4464-8. [PubMed: 3520574]

27. Weidner N, Austen KF. Heterogeneity of mast cells at multiple body sites. Fluorescent determination of avidin binding and immunofluorescent determination of chymase, tryptase, and carboxypeptidase content. Pathol Res Pract. 1993; 189:156-62. [PubMed: 8321743]

28. Yamada M, Ueda M, Naruko T, Tanabe S, Han YS, Ikura Y, et al. Mast cell chymase expression and mast cell phenotypes in human rejected kidneys. Kidney Int. 2001; 59:1374-81. [PubMed: 11260398]

29. Dougherty RH, Sidhu SS, Raman K, Solon M, Solberg OD, Caughey GH, et al. Accumulation of intraepithelial mast cells with a unique protease phenotype in $\mathrm{T}(\mathrm{H}) 2$-high asthma. J Allergy Clin Immunol. 2010; 125:1046-53 e8. [PubMed: 20451039]

30. Maaninka K, Lappalainen J, Kovanen PT. Human mast cells arise from a common circulating progenitor. J Allergy Clin Immunol. 2013; 132:463-9 e3. [PubMed: 23582567]

31. Galli SJ, Nakae S, Tsai M. Mast cells in the development of adaptive immune responses. Nat Immunol. 2005; 6:135-42. [PubMed: 15662442]

32. Hofmann AM, Abraham SN. New roles for mast cells in modulating allergic reactions and immunity against pathogens. Curr Opin Immunol. 2009; 21:679-86. [PubMed: 19828301]

33. Marshall JS. Mast-cell responses to pathogens. Nat Rev Immunol. 2004; 4:787-99. [PubMed: 15459670]

34. Metz M, Siebenhaar F, Maurer M. Mast cell functions in the innate skin immune system. Immunobiology. 2008; 213:251-60. [PubMed: 18406371]

35. Fukuda M, Ushio H, Kawasaki J, Niyonsaba F, Takeuchi M, Baba T, et al. Expression and functional characterization of retinoic acid-inducible gene-I-like receptors of mast cells in response to viral infection. J Innate Immun. 2013; 5:163-73. [PubMed: 23171655]

36. Graham AC, Hilmer KM, Zickovich JM, Obar JJ. Inflammatory response of mast cells during influenza A virus infection is mediated by active infection and RIG-I signaling. J Immunol. 2013; 190:4676-84. [PubMed: 23526820]

37. Kulka M, Metcalfe DD. TLR3 activation inhibits human mast cell attachment to fibronectin and vitronectin. Mol Immunol. 2006; 43:1579-86. [PubMed: 16280166]

38. Motakis E, Guhl S, Ishizu Y, Itoh M, Kawaji H, de Hoon M, et al. Redefinition of the human mast cell transcriptome by deep-CAGE sequencing. Blood. 2014; 123:e58-67. [PubMed: 24671954]

39. McCurdy JD, Olynych TJ, Maher LH, Marshall JS. Cutting edge: distinct Toll-like receptor 2 activators selectively induce different classes of mediator production from human mast cells. $\mathbf{J}$ Immunol. 2003; 170:1625-9. [PubMed: 12574323]

40. Matsushima H, Yamada N, Matsue H, Shimada S. TLR3-, TLR7-, and TLR9-mediated production of proinflammatory cytokines and chemokines from murine connective tissue type skin-derived mast cells but not from bone marrow-derived mast cells. J Immunol. 2004; 173:531-41. [PubMed: 15210814]

41. Varadaradjalou S, Feger F, Thieblemont N, Hamouda NB, Pleau JM, Dy M, et al. Tolllike receptor 2 (TLR2) and TLR4 differentially activate human mast cells. Eur J Immunol. 2003; 33:899-906. [PubMed: 12672055] 
42. Orinska Z, Bulanova E, Budagian V, Metz M, Maurer M, Bulfone-Paus S. TLR3-induced activation of mast cells modulates CD8+ T-cell recruitment. Blood. 2005; 106:978-87. [PubMed: 15840693]

43. Wang Z, Lai Y, Bernard JJ, Macleod DT, Cogen AL, Moss B, et al. Skin mast cells protect mice against vaccinia virus by triggering mast cell receptor S1PR2 and releasing antimicrobial peptides. J Immunol. 2012; 188:345-57. [PubMed: 22140255]

44. Chen X, Niyonsaba F, Ushio H, Hara M, Yokoi H, Matsumoto K, et al. Antimicrobial peptides human beta-defensin (hBD)-3 and hBD-4 activate mast cells and increase skin vascular permeability. Eur J Immunol. 2007; 37:434-44. [PubMed: 17230440]

45. Di Nardo A, Vitiello A, Gallo RL. Cutting edge: mast cell antimicrobial activity is mediated by expression of cathelicidin antimicrobial peptide. J Immunol. 2003; 170:2274-8. [PubMed: 12594247]

46. Campagna S, Saint N, Molle G, Aumelas A. Structure and mechanism of action of the antimicrobial peptide piscidin. Biochemistry. 2007; 46:1771-8. [PubMed: 17253775]

47. Li G, Domenico J, Jia Y, Lucas JJ, Gelfand EW. NF-kappaB-dependent induction of cathelicidinrelated antimicrobial peptide in murine mast cells by lipopolysaccharide. Int Arch Allergy Immunol. 2009; 150:122-32. [PubMed: 19439978]

48. Di Nardo A, Yamasaki K, Dorschner RA, Lai Y, Gallo RL. Mast cell cathelicidin antimicrobial peptide prevents invasive group A Streptococcus infection of the skin. J Immunol. 2008; 180:7565-73. [PubMed: 18490758]

49. von Kockritz-Blickwede M, Goldmann O, Thulin P, Heinemann K, Norrby-Teglund A, Rohde M, et al. Phagocytosis-independent antimicrobial activity of mast cells by means of extracellular trap formation. Blood. 2008; 111:3070-80. [PubMed: 18182576]

50. Sugiyama K. Histamine release from rat mast cells induced by Sendai virus. Nature. 1977; 270:614-5. [PubMed: 74020]

51. Mokhtarian F, Griffin DE. The role of mast cells in virus-induced inflammation in the murine central nervous system. Cell Immunol. 1984; 86:491-500. [PubMed: 6329524]

52. Sorden SD, Castleman WL. Virus-induced increases in airway mast cells in brown Norway rats are associated with enhanced pulmonary viral replication and persisting lymphocytic infiltration. Exp Lung Res. 1995; 21:197-213. [PubMed: 7774525]

53. King CA, Marshall JS, Alshurafa H, Anderson R. Release of vasoactive cytokines by antibodyenhanced dengue virus infection of a human mast cell/basophil line. J Virol. 2000; 74:7146-50. [PubMed: 10888655]

54. Brown MG, Huang YY, Marshall JS, King CA, Hoskin DW, Anderson R. Dramatic caspasedependent apoptosis in antibody-enhanced dengue virus infection of human mast cells. J Leukoc Biol. 2009; 85:71-80. [PubMed: 18809735]

55. Burke SM, Issekutz TB, Mohan K, Lee PW, Shmulevitz M, Marshall JS. Human mast cell activation with virus-associated stimuli leads to the selective chemotaxis of natural killer cells by a CXCL8-dependent mechanism. Blood. 2008; 111:5467-76. [PubMed: 18424663]

56. Ogunbiyi PO, Black WD, Eyre P. Parainfluenza-3 virus-induced enhancement of histamine release from calf lung mast cells-effect of levamisole. J Vet Pharmacol Ther. 1988; 11:338-44. [PubMed: 2463373]

57. Sun Q, Li W, She R, Wang D, Han D, Li R, et al. Evidence for a role of mast cells in the mucosal injury induced by Newcastle disease virus. Poult Sci. 2009; 88:554-61. [PubMed: 19211524]

58. Aoki R, Kawamura T, Goshima F, Ogawa Y, Nakae S, Nakao A, et al. Mast cells play a key role in host defense against herpes simplex virus infection through TNF-alpha and IL-6 production. J Invest Dermatol. 2013; 133:2170-9. [PubMed: 23528820]

59. Kurt-Jones EA, Chan M, Zhou S, Wang J, Reed G, Bronson R, et al. Herpes simplex virus 1 interaction with Toll-like receptor 2 contributes to lethal encephalitis. Proc Natl Acad Sci U S A. 2004; 101:1315-20. [PubMed: 14739339]

60. Zhu J, Martinez J, Huang X, Yang Y. Innate immunity against vaccinia virus is mediated by TLR2 and requires TLR-independent production of IFN-beta. Blood. 2007; 109:619-25. [PubMed: 16973959] 
61. Wang Z, MacLeod DT, Di Nardo A. Commensal bacteria lipoteichoic acid increases skin mast cell antimicrobial activity against vaccinia viruses. J Immunol. 2012; 189:1551-8. [PubMed: 22772452]

62. Leung AD, Schiltz AM, Hall CF, Liu AH. Severe atopic dermatitis is associated with a high burden of environmental Staphylococcus aureus. Clin Exp Allergy. 2008; 38:789-93. [PubMed: 18341620]

63. Kong HH, Oh J, Deming C, Conlan S, Grice EA, Beatson MA, et al. Temporal shifts in the skin microbiome associated with disease flares and treatment in children with atopic dermatitis. Genome Res. 2012; 22:850-9. [PubMed: 22310478]

64. Matsui K, Nishikawa A. Percutaneous application of peptidoglycan from Staphylococcus aureus induces an increase in mast cell numbers in the dermis of mice. Clin Exp Allergy. 2005; 35:382-7. [PubMed: 15784119]

65. Nakamura Y, Oscherwitz J, Cease KB, Chan SM, Munoz-Planillo R, Hasegawa M, et al. Staphylococcus delta-toxin induces allergic skin disease by activating mast cells. Nature. 2013; 503:397-401. [PubMed: 24172897]

66. Di Virgilio F. Liaisons dangereuses: P2X(7) and the inflammasome. Trends Pharmacol Sci. 2007; 28:465-72. [PubMed: 17692395]

67. Kurashima Y, Amiya T, Nochi T, Fujisawa K, Haraguchi T, Iba H, et al. Extracellular ATP mediates mast cell-dependent intestinal inflammation through P2X7 purinoceptors. Nat Commun. 2012; 3:1034. [PubMed: 22948816]

68. Sudo N, Tanaka K, Koga Y, Okumura Y, Kubo C, Nomoto K. Extracellular ATP activates mast cells via a mechanism that is different from the activation induced by the cross-linking of $\mathrm{Fc}$ receptors. J Immunol. 1996; 156:3970-9. [PubMed: 8621938]

69. Elssner A, Duncan M, Gavrilin M, Wewers MD. A novel P2X7 receptor activator, the human cathelicidin-derived peptide LL37, induces IL-1 beta processing and release. J Immunol. 2004; 172:4987-94. [PubMed: 15067080]

70. Kurashima Y, Amiya T, Fujisawa K, Shibata N, Suzuki Y, Kogure Y, et al. The enzyme Cyp26b1 mediates inhibition of mast cell activation by fibroblasts to maintain skin-barrier homeostasis. Immunity. 2014; 40:530-41. [PubMed: 24726878]

71. Scharschmidt TC, Yost JM, Truong SV, Steinhoff M, Wang KC, Berger TG. Neurogenic rosacea: a distinct clinical subtype requiring a modified approach to treatment. Arch Dermatol. 2011; 147:123-6. [PubMed: 21242409]

72. Yamasaki K, Di Nardo A, Bardan A, Murakami M, Ohtake T, Coda A, et al. Increased serine protease activity and cathelicidin promotes skin inflammation in rosacea. Nat Med. 2007; 13:97580. [PubMed: 17676051]

73. Yamasaki K, Kanada K, Macleod DT, Borkowski AW, Morizane S, Nakatsuji T, et al. TLR2 expression is increased in rosacea and stimulates enhanced serine protease production by keratinocytes. J Invest Dermatol. 2011; 131:688-97. [PubMed: 21107351]

74. Holmes AD. Potential role of microorganisms in the pathogenesis of rosacea. J Am Acad Dermatol. 2013; 69:1025-32. [PubMed: 24011460]

75. Muto Y, Wang Z, Vanderberghe M, Two A, Gallo RL, Di Nardo A. Mast cells are key mediators of cathelicidin-initiated skin inflammation in rosacea. J Invest Dermatol. 2014; 134:2728-36. [PubMed: 24844861]

76. Kanada KN, Nakatsuji T, Gallo RL. Doxycycline indirectly inhibits proteolytic activation of tryptic kallikrein-related peptidases and activation of cathelicidin. J Invest Dermatol. 2012; 132:1435-42. [PubMed: 22336948]

77. Hoffman HM, Mueller JL, Broide DH, Wanderer AA, Kolodner RD. Mutation of a new gene encoding a putative pyrin-like protein causes familial cold autoinflammatory syndrome and Muckle-Wells syndrome. Nat Genet. 2001; 29:301-5. [PubMed: 11687797]

78. Neven B, Prieur AM, Quartier dit Maire P. Cryopyrinopathies: update on pathogenesis and treatment. Nat Clin Pract Rheumatol. 2008; 4:481-9. [PubMed: 18665151]

79. Franchi L, Munoz-Planillo R, Nunez G. Sensing and reacting to microbes through the inflammasomes. Nat Immunol. 2012; 13:325-32. [PubMed: 22430785] 
80. Nakamura Y, Franchi L, Kambe N, Meng G, Strober W, Nunez G. Critical role for mast cells in interleukin-1beta-driven skin inflammation associated with an activating mutation in the nlrp3 protein. Immunity. 2012; 37:85-95. [PubMed: 22819042]

81. Nakamizo S, Egawa G, Honda T, Nakajima S, Belkaid Y, Kabashima K. Commensal bacteria and cutaneous immunity. Semin Immunopathol. 2015; 37:73-80. [PubMed: 25326105]

82. Lai Y, Di Nardo A, Nakatsuji T, Leichtle A, Yang Y, Cogen AL, et al. Commensal bacteria regulate Toll-like receptor 3-dependent inflammation after skin injury. Nat Med. 2009; 15:1377-82. [PubMed: 19966777]

83. Wang Z, M N, Eckmann L, Miyamoto Y, Sun X, Kawakami T, Di Nardo A. Skin microbiome promotes mast cell maturation by triggering stem cell factor (SCF) production in keratinocytes. Journal of Allergy and Clinical Immunology. 2016 Accepted for publication. 


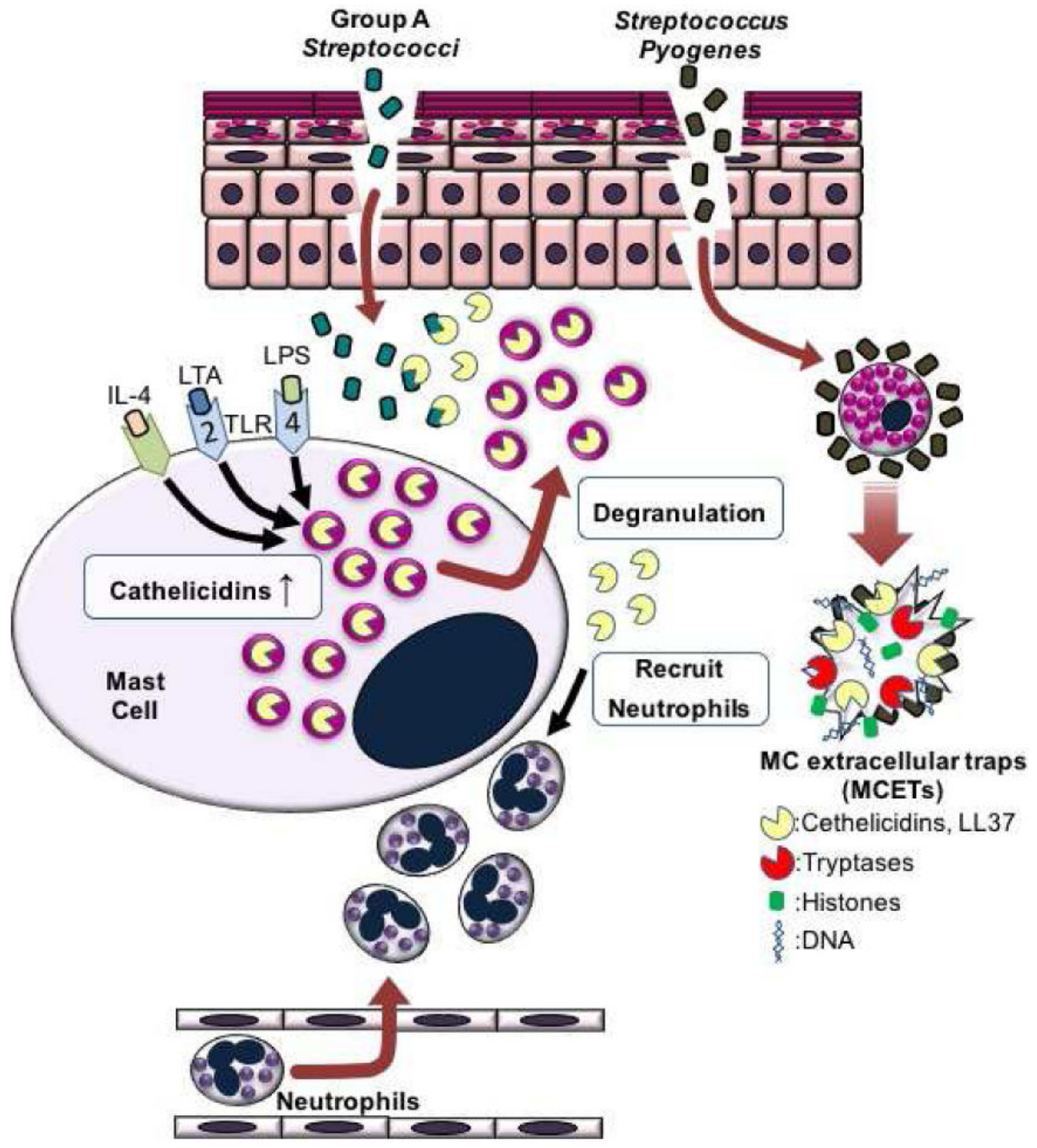

Figure 1. The two roles of mast cells (MCs) in bacterial infection

In group A Streptococcus skin infection, MC cathelicidin (LL-37) expression is increased by IL-4 and ligands of TLR2 and -4. The cathelicidins derived from MCs (LL-37) can not only kill bacteria directly, but also facilitate recruitment of neutrophils. On the other hand, MCs can show different antimicrobial activity against Streptococcus pyogenes, when they are exposed to a large number of bacteria, by emitting extracellular structures called MC extracellular traps (MCETs). IL-4: interleukin 4, LPS: lipopolysaccharide, LTA: lipoteichoic acid, TLR: Toll-like receptor 


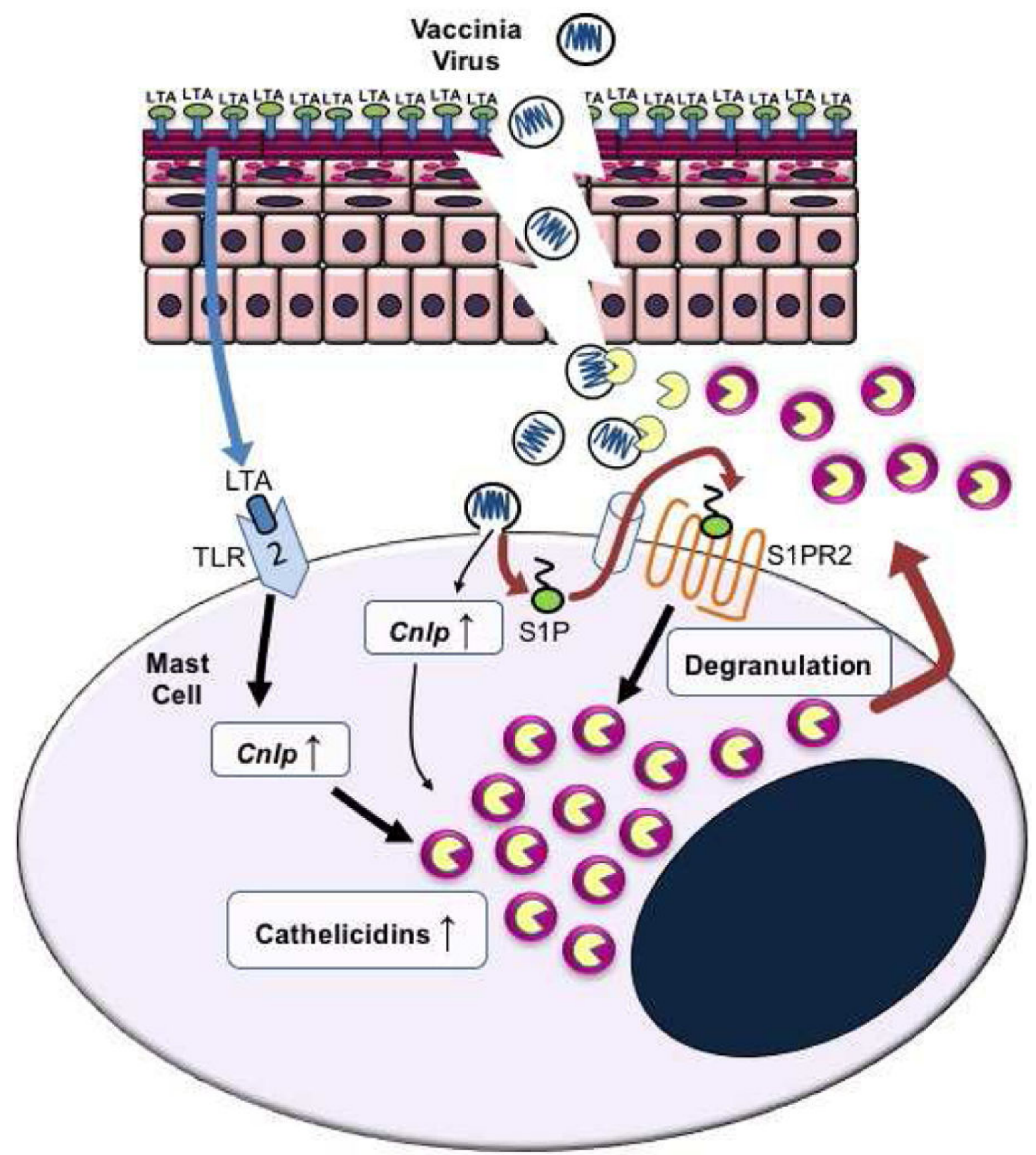

Figure 2. Skin microbiome-derived LTA reinforces the clearance of vaccinia virus (VV) with increasing antimicrobial peptide (AMP) expression in mast cells (MCs)

LTA derived from the commensal microbiome on the skin surface increases the expression of cathelicidins in MC granules via induction of Cnlp. TLR2 mediates this LTA-Cnlp response. VV challenge to MCs can also induce weak Cnlp expression in MCs, but this pathway is not mediated by TLR2. When VV enter MCs by membrane fusion, this event induces S1P formation and S1PR2 activation, leading to MC degranulation. Cnlp: cathelicidin-like protein, LTA: lipoteichoic acid, S1P: sphingosine-1-phosphate, S1PR2: S1P receptor 2, TLR: Tolllike receptor 


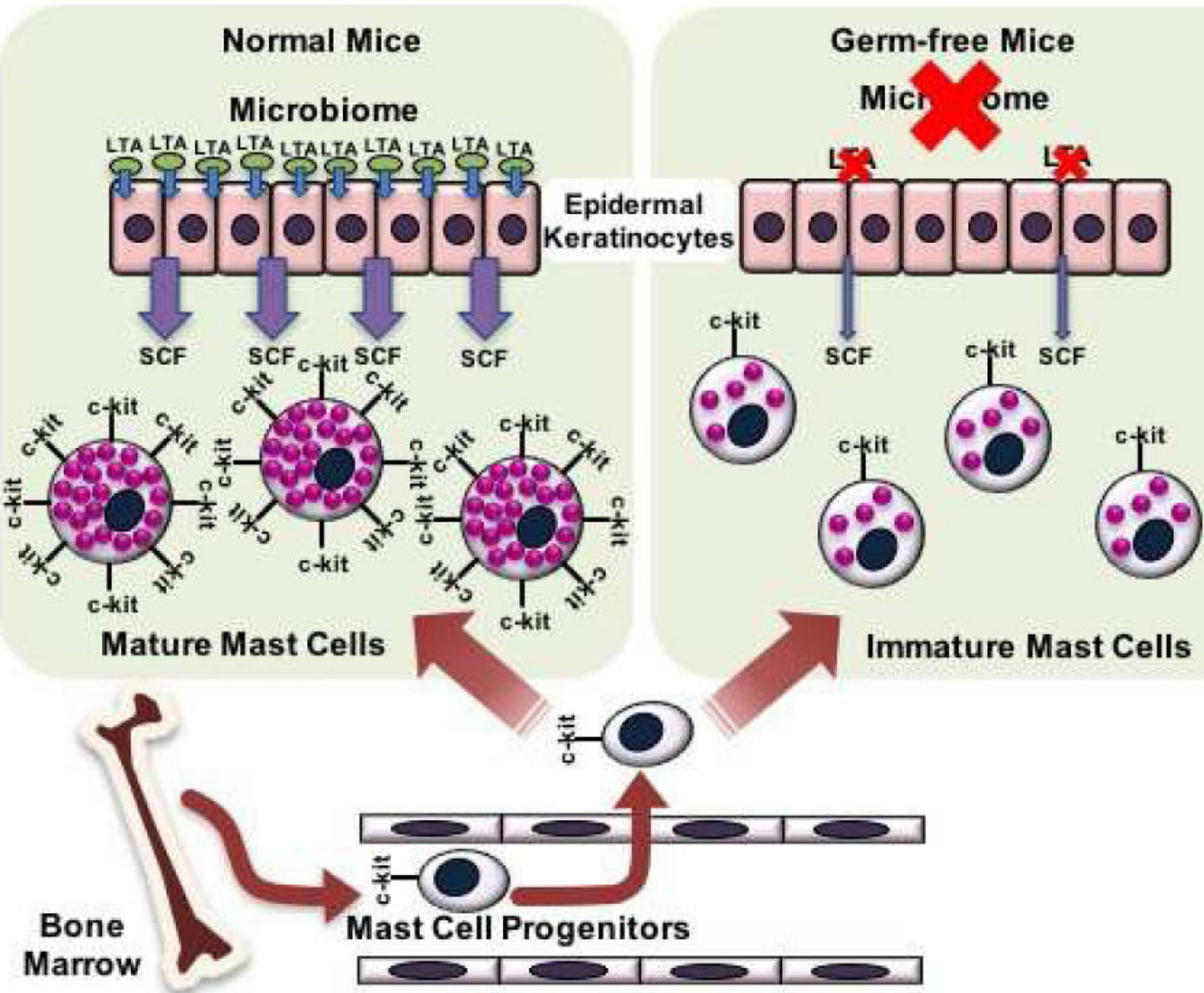

Figure 3. Commensal skin microbiome promotes mast cell (MC) maturation In a normal mouse, LTA from the skin microbiome induces keratinocytes to produce sufficient SCF, which results in proper MC maturation. In germ-free mice, MCs present lower expressions of the c-Kit and IgE receptors because SCF is insufficient. c-kit (CD117): mast/stem cell growth factor receptor, LTA: lipoteichoic acid, SCF: stem cell factor 


\section{Table 1}

The differences in mature mast cell phenotypes in tissues

\begin{tabular}{ccccc}
\hline & Skin $^{[22,25]}$ & Small intestine $^{[22]}$ & Lung $^{[22]}$ & Trachea $^{[22]}$ \\
\hline MMC & & mMCP-1 & mMCP-1, 2, 6, 7 & mMCP-1, 2, 4, 5, 6, 7, CPA3 \\
CTMC & mMCP-4, 5, 6, 7, CPA3 & mMCP-4, 5, 6, 7, CPA3 & mMCP-1, 2, 4, 5, 6, 7, CPA3 & mMCP-1, 2, 4, 5, 6, 7, CPA3 \\
\hline
\end{tabular}




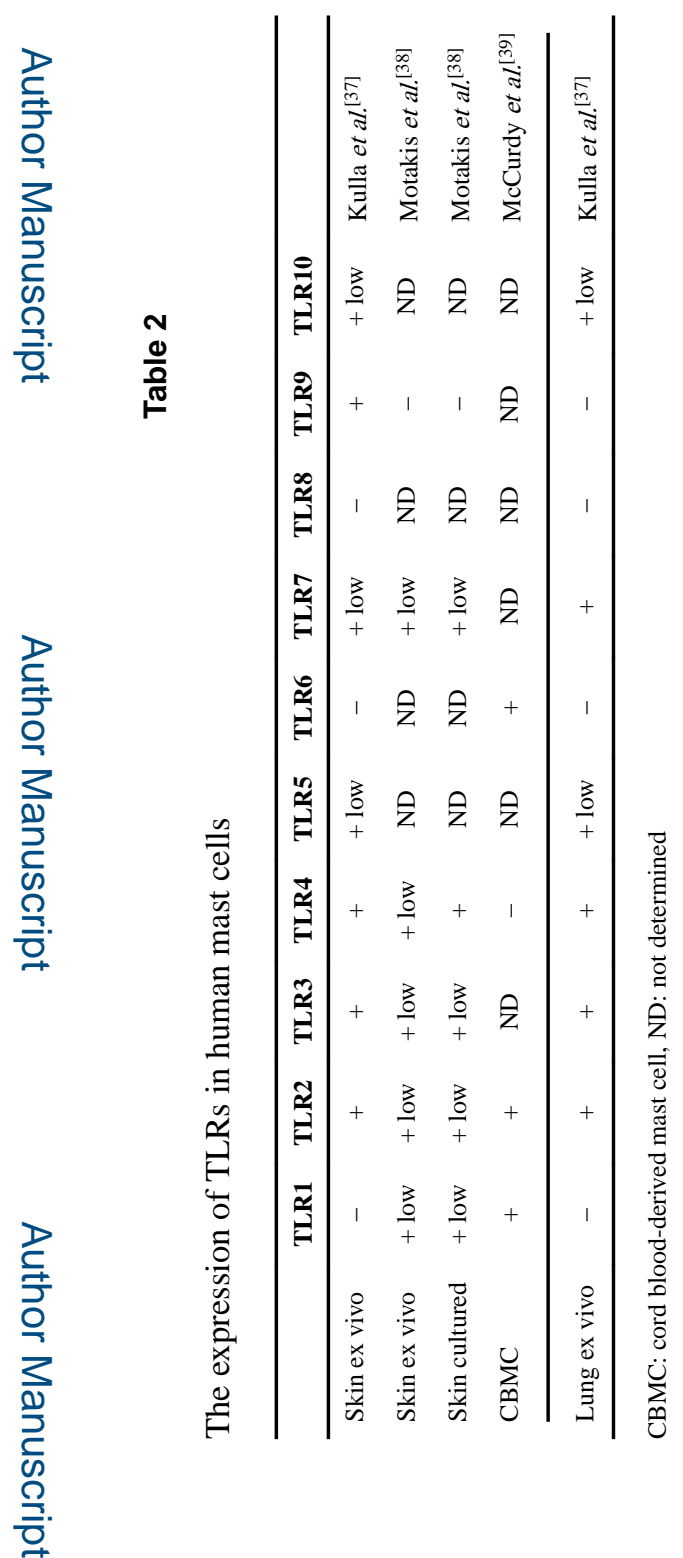

Transl Res. Author manuscript; available in PMC 2018 June 01. 